\title{
Immature life cycle of laboratory-reared Phylloicus elektoros and Phylloicus amazonas (Trichoptera: Calamoceratidae) from a central Amazonian stream
}

\author{
Renato Tavares MARTINS*(®), Kleicy Maciel SOARES, Neusa HAMADA \\ Instituto Nacional de Pesquisas da Amazônia-INPA, Coordenação de Biodiversidade-COBIO, Manaus, Amazonas, Brazil \\ * Corresponding author: martinsrt@gmail.com; (D) https://orcid.org/0000-0003-3464-7905
}

\begin{abstract}
We reared field-collected egg masses of the caddisflies Phylloicus amazonas $(\mathrm{n}=2)$ and Phylloicus elektoros $(\mathrm{n}=7)$ to adulthood. First instar larvae of both species hatched up to five days after field collection. Median development time from first larval instar to adult was 229 days for $P$. amazonas and 275 for $P$. elektoros, including the pupal development time (median of 13.5 and 16 days, respectively). Shredder organisms have been used frequently in studies related to organic matter processing in freshwater ecosystems. The biological information reported in here may be useful for the design of experimental studies in the field or under laboratory conditions.
\end{abstract}

KEYWORDS: aquatic insects, development time, life stages, organic matter, shredders

\section{Ciclo de vida em laboratório de imaturos de Phylloicus elektoros e Phylloicus amazonas (Trichoptera: Calamoceratidae) de um igarapé da Amazônia Central}

\section{RESUMO}

Nós criamos massas de ovos dos tricópteros Phylloicus amazonas $(\mathrm{n}=2)$ e Phylloicus elektoros $(\mathrm{n}=7)$ coletadas no campo até a fase adulta. A mediana do tempo de desenvolvimento do primeiro instar larval ao adulto foi de 229 dias para $P$. amazonas e 275 dias para P. elektoros, incluindo o tempo de desenvolvimento pupal (mediana de 13.5 e 16 dias, respectivamente). Fragmentadores têm sido frequentemente usados em estudos relacionados ao processamento de matéria orgânica em ecossistemas aquáticos. As informaçôes biológicas fornecidas neste estudo podem ser úteis para o planejamento de estudos experimentais em campo ou em condiçóes de laboratório.

PALAVRAS-CHAVE: insetos aquáticos, tempo de desenvolvimento, fases de vida, matéria orgânica, fragmentadores

Trichoptera is one of the most diverse aquatic insect orders with 16,267 extant species (Morse et al. 2020). The adults are terrestrial and, in general, the remaining life stages live in aquatic environments (Pes et al. 2019). Species in this order can be classified into different functional feeding groups (e.g., collector-filterers, scrapers, shredders and predators) and play an important role in the food chain of aquatic environments (Morse et al. 2019). For example, shredders transform coarse particulate organic matter (e.g., leaves) into smaller fractions (Vannote et al. 1980), making food available to other invertebrates and vertebrates through the decomposition process (González and Graça 2003). Phylloicus Müller, 1880 (Trichoptera: Calamoceratidae) species are fundamental shredders in low-order Neotropical streams
(Martins et al. 2015; Souza-Holanda et al. 2020). Due to their importance in the decomposition of organic matter in aquatic environments, Phylloicus larvae have been used in several laboratory experiments (e.g., Martins et al. 2017a,b; Martins et al. 2020; Rezende et al. 2020; Sena et al. 2020).

Currently, 62 species of Phylloicus are known from Central, North and South America (Morse 2020). Approximately $42 \%$ of these have been recorded in Brazil (Calor and Santos 2020). However, little is known worldwide about the biology of species in this genus. Life history information is provided only for three species: Phylloicus elegans Hogue \& Denning, Phylloicus ornatus (Banks) from Costa Rica (Jackson and Sweeney 1995) and U.S.A. (Norwood and Stewart 2002), and Phylloicus pulchrus Flint from Puerto Rico (Reyes-Torres and 
Ramírez 2018). Considering the relevance of Phylloicus larvae in the processing of organic matter in Amazonian aquatic environments, it is important to have regionally-specific information regarding the biology of this shredder because the development time may differ among species, geographic regions, and laboratory rearing modes (Jacobsen et al. 2008). Here we provide information about the life cycle of two central Amazonian species, Phylloicus amazonas Prather and Phylloicus elektoros Prather, to support future laboratory and field experiments related to organic matter decomposition in streams.

We collected Phylloicus egg masses in August and November 2015 in the forest reserve "Reserva Florestal Ducke” (RFD; 0255'-0301'S, 5953-59०59'W), Manaus, Amazonas state, Brazil. The RFD has about $100 \mathrm{~km}^{2}$ of dense rainforest, relative humidity above $75 \%$ and annual rainfall of 1750 to $2500 \mathrm{~mm}$ (Ferreira et al. 2012). Collections occurred in Igarapé Barro Branco, a whitewater stream with dense riparian vegetation, acidic water $(\mathrm{pH}=4.6 \pm 0.1)$, low electrical conductivity $\left(10.7 \pm 0.4 \mu \mathrm{S} \mathrm{cm} \mathrm{cm}^{-1}\right)$ and mean temperature and dissolved oxygen of $24.5 \pm 0.5^{\circ} \mathrm{C}$ and 6.6 $\pm 0.1 \mathrm{mg} \mathrm{l}^{-1}$, respectively (Martins et al. 2014). Egg masses were located above the water surface, in the vegetation close to the stream banks. In total, 17 egg masses were collected manually, seven in August and 10 in November. At least three Phylloicus species occur in the RFD (P. amazonas, P. elektoros and Phylloicus fenestratus Flint; Souza-Holanda et al. 2020). The egg masses of the three species have similar morphological appearance which makes it impossible to distinguish among species in the field. To morphologically distinguish imatures and adults of these three species see Campos (2019) and Souza-Holanda et al. (2020). The egg masses were taken to the laboratory where they remained at constant temperature $\left(22{ }^{\circ} \mathrm{C}\right)$ in individual polystyrene boxes containing water from the stream and leaf discs of Goupia glabra Aubl., and covered with mesh. The leaf discs served as food and for case construction by the larvae. The leaf discs were incubated for 14 days in fine-mesh $(0.5 \mathrm{~mm})$ litter bags to leach water-soluble compounds and for conditioning by microorganisms (Gessner et al. 1999). During rearing, a photoperiod of $12 \mathrm{~h}$ light: $12 \mathrm{~h}$ dark was maintained. We changed the water in the boxes every two days. Bryophytes were inserted in the boxes to reduce the proliferation of microorganisms (Ferreira and Rafael 2006). We recorded the survival of eggs and immatures daily.

In eight of the 17 collected egg masses, all individuals died in the larval stage making species-level identification impossible. We obtained adults from the remaining nine egg masses, of which two belonged to Phylloicus amazonas and seven to P. elektoros. For both species, we calculated the median time for development and the number of specimens in each stage (larva, pupa and adult), except for the egg. For each species, we deposited two speciems in the invertebrate collection of Instituto Nacional de Pesquisas da Amazônia (INPA), Manaus, Brazil.

The eggs of $P$. amazonas and P. elektoros are circular and immersed in spumaline (a gelatinous-like mass, Morse et al. 2019). Since eggs were not collected at the moment of oviposition, it was not possible to determine the exact time required for incubation time. First-instar larvae hatched five days after collection in the field, indicating this period as the minimum time for embryo development.

Larvae of $P$. amazonas left the egg mass after four days of hatching. The median number of first-instar larvae emerging from the two egg masses was 51.5 (range $46-57$ ), yet only seven individuals reached the pupal stage, and two (one male and one female) reached the adult stage. The median development time from first instar to adult was 229 days (range 209 - 249), median larval development took 215.5 days (range 202 - 229) and median pupal developmental time was 13.5 days (range $7-20 ; \mathrm{n}=7$ pupae).

For $P$. elektoros, larvae left the egg mass after three days (median value), varying from one to four days. We recorded median values of 67 first-instar larvae per egg mass (range $26-97)$, 1 pupa (range $1-2$ ) and 1 adult (range $1-1$ ). In total, only 10 pupae and seven adults (five males and two females) were obtained. Median developmental time from first instar to adult was 275 days (range 245 - 321), median larval-stage development time was 251 days (range 238 - 302), and median pupal development time was 16 days (range 7 $20, \mathrm{n}=10$ pupae).

The eggs of $P$. amazonas and P. elektoros are similar to what was observed for other species of Phylloicus (e.g., Norwood and Stewart 2002; Bentes et al. 2019). Larvae of P. elegans, P. ornatus, and Phylloicus nr. ornatus left the egg masses 10 to 16 days after oviposition, but no information was provided on the time larvae remained inside the egg masses after the first-instars hatched (Jackson and Sweeney 1995).

A high larval mortality rate was observed for both species in our study, with less than $2 \%$ of hatched larvae reaching adulthood. In general, studies on Phylloicus biology have not indicated the mortality rate. However, for P. fenestratus, from 120 larvae hatched, only seven individuals reached adulthood (Souza-Holanda et al. 2020), and, during one year of collection in a stream, 1347 larvae and only 49 adults of $P$. pulchrus were sampled, indicating a high mortality rate (Reyes-Torres and Ramírez 2018). In contrast, under laboratory conditions, Jackson and Sweeney (1995) recorded a high number of adults for P. ornatus (35 egg masses and 1404 adults) and Phylloicus nr. ornatus (five egg masses and 386 adults) from egg masses oviposited by field-collected gravid females.

The median time from first instar to adult reported in the literature was 72 days for P. elegans in Costa Rica (Jackson and Sweeney 1995), 122 days for P. pulchrus in Puerto Rico (Reyes-Torres and Ramírez 2018) and 110 and 115.5 days 
for $P$. ornatus in Costa Rica and U.S.A., respectively (Jackson and Sweeney 1995; Norwood and Stewart 2002). For $P$. fenestratus from Amazonia, larval development varied from 120 to 135 days, and adults emerged after 7 to 10 days of pupation (Souza-Holanda et al. 2020). Thus, the development time from first instar to adult of $P$. amazonas and P. elektoros in our study was up to 3.8 times longer than that known for other species of Phylloicus. We reared Phylloicus specimens at a constant temperature of $22{ }^{\circ} \mathrm{C}$, similar to the studies cited above (constant temperatures between 20 and $23^{\circ} \mathrm{C}$; Jackson and Sweeney 1995; Reyes-Torres and Ramírez 2018). Our rearing temperature was $2.5^{\circ} \mathrm{C}$ below the temperature of the stream water at the collection site of the eggs masses (Martins et al. 2014). We believe that temperature was not the main factor influencing the longer development time of P. amazonas and P. elektoros. Although we provided more food than the larvae demanded, we cannot discard the effects of laboratory conditions on our results. For example, the use of only one plant species (G. glabra), although previously used in other studies (Martins et al. 2017a), may have limited the supply of nutrients to individuals, since the riparian forest along the stream where the eggs were collected containes a large number of different plant species (62 species within 10 $\times 100 \mathrm{~m}$; Tonin et al. 2017).

\section{ACKNOWLEDGMENTS}

We thank M.Sc. Gleison R. Desiderio for Phylloicus species identification and Philip M. Fearnside for support with the English version. RTM received a fellowship from Programa de Apoio à Fixação de Doutores no AmazonasFIXAM/AM (Fundaçáo de Amparo à Pesquisa do Estado do Amazonas- FAPEAM). KMS received a PIBIC scholarship from Conselho Nacional de Desenvolvimento Científico e Tecnológico $(\mathrm{CNPq})$. $\mathrm{NH}$ received research grants from CNPq (308970/2019-5) and INPA/MCTI. The present work was supported in part by project INCT ADAPTA II funded by CNPq (465540/2014-7), FAPEAM (0621187/2017), Coordenaçáo de Aperfeiçoamento de Pessoal de Nível Superior (CAPES), and FAPEAM-Program POSGRAD2019.

\section{REFERENCES}

Bentes, S.P.C.; Hamada, N.; Ferreira-Keppler, R.L. 2019. Caracterização morfológica de ovos de insetos aquáticos e seus habitats na Amazônia central, Brasil. In: Hamada, N.; Nessimian, J.L.; Querino, R.B. (Ed.). Insetos aquáticos na Amazônia brasileira: taxonomia, biologia e ecologia. Editora INPA, Manaus, p.49-67.

Calor, A.R.; Santos, A.P.M. 2020. Calamoceratidae. In: Boeger, W.A.; Zaher, H.; Rafael, J.A.; Valim, M.P. (Ed.). Taxonomic Catalog of the Brazilian Fauna. UNO/PNUD Brasil, Brasília. (http://fauna.jbrj.gov.br/fauna/faunadobrasil/10134). Accessed on 18 Aug 2020.

Campos, C.M. 2019. Taxonomia e o efeito do aumento da temperatura e dióxido de carbono (CO2) sobre imaturos de Phylloicus Müller 1880
(Trichoptera: Calamoceratidae) da Amazônia Central. Master's dissertation, Instituto Nacional de Pesquisas da Amazônia, Brazil. 87p. (https://repositorio.inpa.gov.br/handle/1/36477). Accessed on 14 Jan/2021.

Ferreira, R.L.M.; Rafael, J.A. 2006. Criação de imaturos de mutuca (Tabanidae: Diptera) utilizando briófitas e areia como substrato. Neotropical Entomolology, 35:141-144.

Ferreira, S.J.F.; Miranda, S.A.F.; Marques Filho, A.O.; Silva, C.C. 2012. Efeito da pressão antrópica sobre igarapés na Reserva Florestal Adolpho Ducke, área de floresta na Amazônia Central. Acta Amazonica, 42: 533-540.

Gessner, M.O.; Chauvet, E.; Dobson, M. 1999. A perspective on leaf litter breakdown in streams. Oikos, 5: 377-384.

González, J.; Graça, M.A. 2003. Conversion of leaf litter to secondary production by a shredding caddis-fly. Freshwater Biology, 48: 1578-1592.

Jackson, J.K.; Sweeney, B.W. 1995. Egg and larval development times for 35 species of Tropical stream insects from Costa Rica. Journal of the North American Benthological Society, 14: 115-130.

Jacobsen, D.; Cressa, C.; Mathooko, J.; Dudgeon, D. 2008. Macroinvertebrates: composition, life histories and production. In: Dudgeon, D. (Ed.). Tropical Stream Ecology. Academic Press, Cambridge, p.65-105.

Martins, R.T.; Melo, A.S.; Gonçalves Júnior, J.F.; Hamada, N. 2014. Estimation of dry mass of caddisflies Phylloicus elektoros (Trichoptera: Calamoceratidae) in a Central Amazon stream. Zoologia, 31: 337-342.

Martins, R.T.; Melo, A.S.; Gonçalves Jr., J.F.; Hamada, N. 2015. Leaf-litter breakdown in urban streams of Central Amazonia: direct and indirect effects of physical, chemical, and biological factors. Freshwater Biology, 34: 716-726.

Martins, R.T.; Melo, A.S.; Gonçalves Júnior, J.F.; Campos, C.M.; Hamada, N. 2017a. Effects of climate change on leaf breakdown by microorganisms and the shredder Phylloicus elektoros (Trichoptera: Calamoceratidae). Hydrobiologia, 789: 31-44.

Martins, R.T.; Rezende, R.S.; Gonçalves Júnior, J.F.; Lopes, A.; Piedade, M.T.F.; Cavalcante, H.L.; Hamada, N. 2017b. Effects of increasing temperature and, $\mathrm{CO}_{2}$ on quality of litter, shredders, and microorganisms in Amazonian aquatic systems. Plos One, 12: e0188791.

Martins, R.T.; Gonçalves Jr., J.F.; Campos, C.M.; Lopes, A.; Piedade, M.T.F.; Hamada, N. 2020. Leaf consumption by invertebrate aquatic shredders in the Amazon: effects of climate change and microbial conditioning. Limnology, 21: 257-266.

Morse, J.C. 2020. Trichoptera World Checklist. (http://entweb. clemson.edu/database/trichopt/index.htm). Accessed on 20 Aug 2020.

Morse, J.C.; Frandsen, P.B.; Graf, W.; Thomas, J.A. 2019. Diversity and ecosystem services of Trichoptera. Insects, 10: 125. doi: $10.3390 /$ insects 10050125

Norwood, J.C.; Stewart, K.W. 2002. Life history and case-building behavior of Phylloicus ornatus (Trichoptera: Calamoceratidae) in two spring-fed streams in Texas source. Annals of the Entomological Society of America, 95: 44-56. 
Pes, A.M.; Santos, A.P.M.; Barcelos-Silva, P.; de Camargos, L.M. 2019. Ordem Trichoptera. In: Hamada, N.; Nessimian, J.L.; Querino, R.B. (Ed.). Insetos Aquáticos na Amazônia Brasileira: Taxonomia, Biologia e Ecologia. Editora INPA, Manaus, p.387429.

Reyes-Torres, L.J.; Ramírez, A. 2018. Life history and phenology of Phylloicus pulchrus (Trichoptera: Calamoceratidae) in a tropical rainforest stream of Puerto Rico. Revista de Biología Tropical, 66: 814-825.

Rezende, R.S.; Bernardi, J.P.; Gomes, E.S.; Martins, R.T.; Hamada, N.; Gonçalves Jr., J.F. 2020. Effects of Phylloicus case removal on consumption of leaf litter from two Neotropical biomes (Amazon rainforest and Cerrado savanna). Limnology. doi.org/10.1007/ s10201-020-00628-w

Sena, G.; Gonçalves Júnior, J.F.; Martins, R.T.; Hamada, N.; Rezende, R.S. 2020. Leaf litter quality drives the feeding by invertebrate shredders in tropical streams. Ecology and Evolution 10: $8563-8570$.

Souza-Holanda, P.M.; Pes, A.M.; Hamada, N. 2020. Immature stages of three species and new records of five species of Phylloicus Müller (Trichoptera, Calamoceratidae) in the northern region of Brazil. Zootaxa, 4851: 111-136.

Tonin, A.M.; Gonçalves Jr., J.F.; Bambi, P.; Couceiro, S.R.M.; Feitoza, L.A.M.; Fontana, L.E.; et al. 2017. Plant litter dynamics in the forest-stream interface: precipitation is a major control across tropical biomes. Scientific Reports, 7: 10799.

Vannote, R.L.; Minshall, G.W.; Cummins, K.W.; Sedell, J.R.; Cushing, C.E. 1980. The river continuum concept. Canadian Journal of Fisheries and Aquatic Sciences, 37: 130-137.

RECEIVED: 08/09/2020

ACCEPTED: 05/01/2021

ASSOCIATE EDITOR: Pitágoras C. Bispo 